\title{
Ensuring Sustainable Development of the Regional Economy in Conditions of Russia's Accession to the WTO
}

\author{
Khairullov D.S. \\ Garaev I.G. \\ Saypullaev U.A. \\ aKazan Federal University, Kazan, 420008, Russia \\ Institute of Economics, Management and Law (Kazan)
}

Doi:10.5901/mjss.2015.v6n1s3p111

\begin{abstract}
The article discloses the concepts and challenges of sustainable development of the regional economy in the current conditions of Russia's accession to the World Trade Organization (WTO), defines necessary conditions for its providing, develops main directions of regional economic policy which conduce to improve the sustainability of the regional economic development, recommends management tools
\end{abstract}

Keywords: sustainable development of the regional economy; the challenges of sustainable regional economic development in the conditions of WTO's market; regional economic policy, government regulation tools are recommended the instruments of state regulation

\section{Introduction}

In modern conditions of Russia's accession to the WTO the actual task is to ensure the sustainable development of the regional economy.

It requires a study of the concept and entity of sustainable development of the regional economy, of the conditions and factors of its ensuring. It is no less important to study the relationship between the sustainable development of the regional economy and the economic stability of its systems within the framework of the mechanism of regional economic development, the source of which is the production of the gross regional product (GRP).

The sustainable development of the regional economy, along with the general laws of development of the national economy is determined by the specific features which are related to the structure of the gross regional product (GRP), a specific gravity of competitive products of the basic economic industries, including exports to total production in the region, security resource potential income and the mentality of the population.

Depending on this, the problems arising in the conditions sustainable development of the regional economy in the conditions of WTO market will have their regional features.

Solving the sustainable development problems of the regional economy requires new approaches in determining the regional economic policy, strengthening the regulatory role of the state in managing the sustainable development of the regional economy, the development of the effective systems, tools and methods of state regulation.

\section{The Methodology}

In the modern conditions of Russia's accession to the WTO the actual task is to ensure security and stability of the national economy. The regions of Russia, being in the common economic space of the country play an important role in the processes of ensuring the security and stability of the national economy. Therefore, the determining factor of security and stability of the national economy in terms of Russia's accession to the WTO becomes a sustainable development of the regional economy.

The aim is to reveal the concept and essence of sustainable development of regional economy, the main problems and conditions of its ensuring in the current conditions of Russia's accession to the World Trade Organization (WTO). In the work the main directions of the regional economic policy which conduce to improve the sustainability of the regional economic development, are developed, government regulation tools are recommended. 


\section{The Results}

In current terms of accession of Russian Federation to the WTO safe and sustainable development of the national economy becomes the urgent task.

All the regions of the Russian Federation, existing in the single economic scope, play an important role in the processes of security provision and sustainable development of the national economy. Therefore, a key factor of sustainable development of the national economy is determined by sustainable development of the regional economy.

The sustainable development of the regional economy depends on the level of self-sufficiency and self-financing in the region.

The level of self-sufficiency of the region, means it's security of production, labor and natural resources, development of science, innovation and investment potential, the presence of structure-competitive industries, the products of which has a dominant position in the economy of the region. Trade balance of export-import of goods in the region, including the foreign trade balance should be steadily positive.

Appropriate level of self-sufficiency in the region allows it to pursue an independent economic directed on ensuring the sustainable development of the regional economy.

The stability of self-financing of the regional economy of the region is provided by conductingfinancial, credit, tax and price policies, the development of the securities market as a source of capital flow into the regional branches of the economy, the establishment of equal relations in the economic field between the federal center and the regions, particularly in the financial relationships with the federal budget, with taking into account the specifics of the region, the development of effective tools of the state regulation of investment and innovation activities, a mechanism of attraction foreign investment to the regional economy, the increase in volumes of competitive export production, increasing per capita income.

The mechanism of attraction foreign investments should promote real investment of foreign financial and material resources to the regional economy, rather than creating the conditions for buying the national wealth at a cheap price.

Regional measures of state support of foreign investments should be carried out in the frames of unified national economic policy and provide the protection of the national interests.

Self-sufficiency of the region (the regional economy) is realized through the obtaining income from commercial activities of business entities territorial-economic complex.

Businesses and organizations objectively unite into the interconnected managing complex to provide extended reproduction process on the basis of costs' self-supporting and maximizing profits.

Sustainable development of the regional economy is determined by the following conditions:

- Economic independence;

- A stable and sustainable development of the regional economy;

- Maintaining the continuous growth of the regional economy.

Thus, the sustainable development of the regional economy consists of three essential elements:

Economic independence. Economic independence of the region expresses the degree of its economic security (primarily financial) resources that allow проводить the independent economic policy, the development of management forms and methods for sustainable development of the regional economy.

Stable and sustainable development of the regional economy is the ability the region's economy to withstand to the various impacts, leading to its decline and a rapid return to the original state in case of nonobservance, or to achieve higher point in its development, steady improvement in the quality of life and ensure a constant expanded reproduction of territorial and economic complex.

Maintaining the continuous growth of the regional economy is based on scientific and technological progress, innovation progressive forms and methods of work organization, the development of effective tools and methods for regulation of investment and innovation.

No less important are the relationship between the sustainable development of the regional economy and the economic stability of its systems as part of the mechanism of regional economic development, the source of which is the production of the gross regional product.

Sustainable development of the regional economy depends on the economic stability of the enterprises, which form a regional economic system. The economic stability of the entity is the ability of the economy to resist and prevent exposure that could lead to a decline in production. The production, which ensures the release of the necessary commodities with minimal costs with efficient using of factors of production and in time. can be steadily developing.

Territorial and economic sustainability of the economic complex of the region is determined by its ability to maintain a continuous expanded reproduction, which is ensuring the stabile increase of a given level of output production and 
economic indicators. Thus, the concept of sustainable development of the regional economy is connected with the economic stability of the material reproduction of territorial-economic complex and in accordance with this is regarded as a socio-economic concept and is defined as a system of economic relations, providing a continuous maintenance of stability and economic growth of the regional economy [9] . It means that the economic sustainability of the economic system of the region is the basis for sustainable development of the regional economy.

Thus, the sustainable development of the regional economy represents such position of the regional economy which is determined by economic stability of its systems which can withstand the negative impacts of different reasons, which are leading to a decline in the economy of the region and a rapid return to the initial steady condition in the case of a breach or reaching a higher point its development.

Sustainable development of the regional economy, which is defined by its economic potential (industrial, financial, labor, academia, innovation, investment, natural), also implies a level of economic development of the region, that maintains a constant process of expanded reproduction of territorial and economic complex that provides a stable growth in the final production and economic indicators, such as the annual GRP growth or maintaining inflation within the limits.

Thus, in our understanding of the sustainable development of the regional economy is a state of development of the economy of the region, defined by its economic potential and stability of its systems, ability to withstand the negative impacts of different reasons, which are leading to a decline in the economy of the region and a rapid return to the initial steady state in If the breach, to maintain a constant process of reproduction of territorial and economic complex that provides a stable growth in the final production and economic indicators.

Sustainable development of the regional economy is possible with the formation of an appropriate regulatory system that ensures stability of final economic and production indicators development. Tools and methods of state regulation in this case are forecasting and programming, budget, price, financial, monetary, tariff and non-tariff methods that are impacting on the economic system of the region and ensuring its stability.

The purpose of the regional economic policy is achieving internal and external stability of the regional economic system. The internal stability of the regional economic system means such state of the economy of the region, which is characterized by the stability of the continuous reproduction of the territorial-economic complex, maintaining a positive trade balance of export-import of production, providing employment and appropriate standard of living of the population. The external resistance is the stability of the regional payment balance, a stable trade surplus, the absence of the external debt, the presence of a stabilization fund (gold reserves), the region's place in the all-Russian and international division of labor.

In general, sustainable development of the regional economy of a particular region along with the general laws of national economic development is determined by specific features: geopolitical and historical, which define the irregularity of the economic development, structure of GRP, a specific gravity of competitive products of basic industries in the total volume of the regional production, the presence of the export sector in the economy of the region, security resource potential (including scientific), incomes of the population. [13].

The Republic of Tatarstan as one of the developed regions of the Russian Federation, has a sufficient economic potential which allows to ensure its sustainable development. This is shown by figures and growth rates of the final economic and industrial development indicators (Figure 1) (falling of the GRP value and the volume of industrial production in 2009 are related to the effects of the global financial crisis).

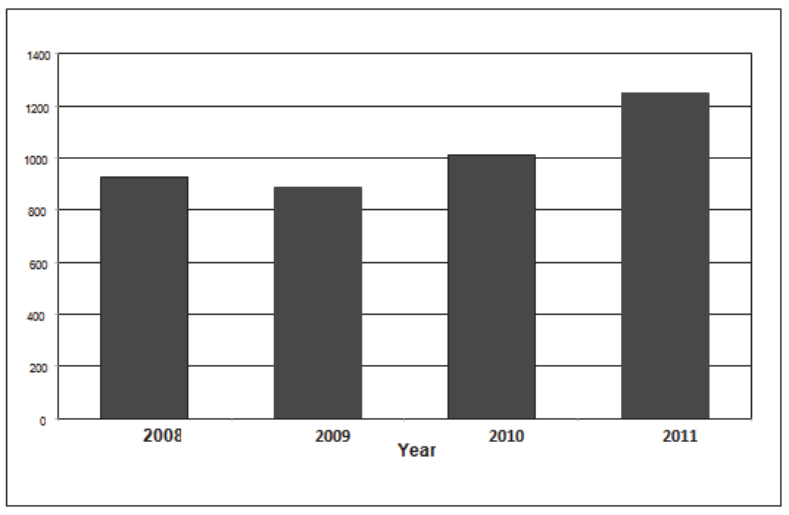

Figure 1. Dynamics of the Tatarstan Republic's GRP 
Investments in fixed assets in 2011 were $386 \mathrm{mlrd} .144 \mathrm{mln}$. rubles, or $142 \%$ compared to 2008 , the growth of agricultural production in 2011 amounted to 150.440 billion rubles, or $129 \%$ in comparable prices to the level of 2008 , the value of the average monthly accrued salary increased from RUR 14,904.0 in 2008 to 20,009.4 in 2011 or 135\% of the level of 2008. [14]

Thus, the level and the growth rate of the final production and economic indicators of Tatarstan Republic, the structure of its economy and the ability of regional economy to withstand the various impacts (crises, etc.) and a rapid return to the original state proves the sustainable development of the regional economy.

In the conditions of WTO market the sustainable development of the regional economy will be determined by the structure of the regional economy. For example, the structure of Tatarstan Republic's GRP has its regional particular qualities: the greatest proportion of its mining (22.9\%) and manufacturing production (15.4\%).[14]

It means that in the conditions of WTO market there may be the threat of losing the external stability of the regional economy as a result of developments conjuncture on the international energy market (for Tatarstan - a decline in oil prices) and the internal stability of the regional economy due to the lack of competitiveness of manufacturing industries enterprises with foreign firms, which may generally lead to a loss of sustainable development of the regional economy. Similar problems may occur in other regions of the Russian Federation as a whole and lead to loss of stability and security of the national economy

Therefore, in the present conditions of Russia's accession to the WTO it is necessary to strengthen the regulatory role of the state in providing security and stability of the regional and national economy. This will require new approaches in defining regional economic policy, the development of an effective system, forms, methods and instruments of state regulation of the regional economy's sustainable development.

The main instruments of state regulation of the regional economy stable development in these conditions are the prediction and programming. The task is to determine the optimal prediction mutually balanced scorecard production and distribution of products in the region, ensuring the achievement of the highest possible level of output production and economic development indicators which allow to support sustainable development of the regional economy. To this end we need to work on the development of economic-mathematical natural-cost inter-sectoral balance model of production and distribution of products, including foreign economic relations, by the sectors of the regional economy. [2] This model allows us to take into account the mutual influence of changes in the economic situation in one of the elements of the economy of all the other (for Tatarstan-15otrasley economy and 50 major industrial and agricultural products). Based on this model there can be made versions of calculations to determine the quantitative estimates of the effects of economic relations on the final production and economic development indicators of the regional economy.

Balance Equation of production and distribution of products in the region:

$X k=\Sigma a k j X j+R k+H k+Z k+V k+W k$

$\mathrm{xk}$ - the volume of production $\mathrm{k} ; \mathrm{Xj}$ - the volume of the industry production; akj - expense ratio of the product $\mathrm{k}$ per unit of $\mathrm{j}$ industry's production; Rk-market funds product $\mathrm{k}$; $\mathrm{Hk}$ - other non-productive consumption; Zk-other elements of the final product; Vk-export volume of region; Wk-import volume in the region;

Using the program LP-88 to calculate with a modified simplex algorithm it is possible to obtain the optimal solution to the problem. As a result of this calculation we determine the optimal forecast of a mutually balanced system of production and distribution indicators, which provides in terms of resource constraints the maximum possible rate of growth of final production and economic indicators of the regional economy's development, allowing to support sustainable development. The using of this predictive tool is particularly relevant in the conditions of WTO market. With it's help you can determine in advance (conducting appropriate market research of WTO market) changes in the economic situation in one of the regional economy's sectors (such as a decline in production volumes as a result of industry competition) and its quantitative impact on the final production and economic indicators for sustainable development of the regional economy. After calculating the forecasts there can be determined: how, and by increasing the production in which sectors of the economy this decline can be compensated to maintain optimal forward-looking indicators of sustainable development of the regional economy. In line with this, the governments make management decisions for the development of programs of state support for the enhance the of the industries competitiveness in these sectors of the economy, conducing to the retention of sustainable development forecast indicators of the regional economy.

In general, we can distinguish the following main challenges facing the region in providing the sustainable development of the regional economy in the conditions of WTO market:

1. Incompatibility of the structure of the regional economy market to the requirements of WTO.

2. The lack of investment for the restructuring of the regional economy.

3. The lack of competitiveness of the region production, the displacement of domestic producers from the 
domestic market as a result of foreign products import that will increase as a result of Russia's accession to the WTO.

4. The threat of food security because of cheap imports

5. Imbalances in the financial sector (financial deficit in the real sector of the economy).

6. The absence of the effective state regulation and tools of sustainable development of regional economy.

7. Underdevelopment of the securities market as a source of capital mobility in the regional industry.

8. Insufficient development of foreign economic relations.

9. Lack of managerial personnel, capable to modern methods of analysis and decision-making for sustainable development of the region.

Solving these problems requires new approaches in determining the regional economic policy, strengthening the regulatory role of the state in the management of sustainable development of the regional economy, the development of effective systems, tools and methods of state regulation.

The priorities of the regional economic policy at this stage should be:

1. The introduction of innovations in the production sphere: using the existing scientific and technical potential of the region, to ensure the steady growth of the economy, leading to a new qualitative stage of development.

2. The development of the programs for developing the regional economy's sectors of the region to meet the challenges of sustainable development of the regional economy

3. The adoption of the state program for the development and support of small businesses, conducing to an increase in the GRP and the creation of new work places.

4. The restructuring of the organizational structure of the regional economy's management in line with the challenges faced in the implementation of industrial, social, investment and science - technology policy to ensure the safety and sustainability of the regional economy in the conditions of WTO market.

5. The organization of the state regulation system of the regional economy's sustainable development.

6. The development effective tools and methods of the regional economy state regulation for it's sustainable growth.

7. Promotion the development of investment activity in the region, creating favorable conditions for attracting foreign investments into the economy of the region.

8. The development of foreign trade, the searching for new markets of products distribution.

9. Ensuring food security in the region.

\section{The conclusions}

In modern conditions of Russia's accession to the WTO the actual task for the region is to ensure the sustainable development of the regional economy. Sustainable development of the regional economy depends on the development of economic potential, economic stability of a regional system, the branch structure of the regional economy. Depending on these factors, the problem of ensuring the sustainable development of the regional economy in terms of Russia's accession to the WTO will have their regional characteristics. The salvation of the problems which prevents the sustainable development of the regional economy requires new approaches in determining the regional economic policy, strengthening the regulatory role of the state in managing the sustainable development of the regional economy, the development of effective systems, tools and methods of state regulation. The main instruments of state regulation are the prediction and programming. The central forecast instrument is an economic-mathematical natural-cost inter-sectoral model of the balance of production and products distribution in the region. By using the calculations based on this model we can obtain quantitative estimates of the impact of changes in the economic situation in one of the elements of a regional system (economic sector, etc.) on the macro and microindicators of sustainable development of the regional economy. Based on these calculations we can determine an optimal prediction of mutually balanced system of production and distribution indicators, which provides the highest possible level of final production and economic indicators of sustainable development of the regional economy in terms of resource constraints. In the conditions of WTO market the problems of sustainable development of the regional economy may happen. This is due to the loss of competitiveness of some industries and sectors of the regional economy as a consequence, the decrease in the level of production. In these circumstances, the role of the instruments (which are named above) is particularly relevant. On this basis you can spend variant forecasts, taking into account the new economic situation in the sector of the regional economy (decrease in production output in the sector, etc.) and determine: by increasing the production of goods of which sectors of the economy, this decrease can be compensated to maintain optimal forward-looking indicators of sustainable development the regional economy. In line with this, the public authorities make their decision on the development programs of state 
support for the development and enhance the competitiveness in the industries in these sectors of the economy of the region, conducing to the sustainable development of regional economy.

The sustainable development of the regional economy in terms of Russia's accession to the WTO requires new approaches in determining the regional economic policy, strengthening the role of the state in economic restructuring in accordance with the tasks arising in the implementation of industrial, social, investment, science, technology and food policy ensuring the security and stability of the regional economy. It is necessary to carry out a restructuring of the management structure of the implementation of the regional economic policy, the formation of an effective system of state regulation of sustainable development, the development of tools and methods of state regulation.

\section{References}

Presidential Decree, May 12, 2009 № 537 "About National Security Strategy of the Russian Federation until 2020", "Rossiyskaya Gazeta" - Federal Issue number 4912 of May 19, 2009.

Input-output economics. Vasily Leontiev. New York Oxford. Oxford university press

Vasily Leontiev. Interindustry economics M: "Economy", 1997 - 478p

Indicators of sustainable development: the structure and methodology. Translated from English. Tyumen Publishing house IFSP SB RAS, 2000

Lvov D.S. Development Economics / D.S. Lvov. M.: Exam $2002-518 p$

Khairullov D.S. Formation of state regulation system of the processes of socio-economic transformation and development of the Republic of Tatarstan, Kazan, "FAN". Tatarstan Academy of Sciences ,1997-236p.

Hamidullin F.G., Khairullov D.S., Khomenko V.V., Tarasov V.M. Problems of management of socio-economic development of the region. Kazan: FAN 2004-192p.

Artyuhov V.V., Zabelin S.I., Lebedeva E.V., Martynov A.S., Mirutenko M.V., Ryzhov I.N. Ratings of sustainable development of the regions of Russia. - M.: "Interfax", 2011.

Ostreykovsky V.A. Analysis of stability and controllability of dynamical systems using methods of catastrophe theory: Textbook for high schools. - M.: High school, 2005 - 326 p.

Glazev C. About strategy of Economic Development of Russia / / Problems of Economics. - 2007. - № 5-p-54-65

Grinberg R. Russian structural policy: between inevitability and uncertainty / / Problems of Economics. - 2008. - № 3. - p. 56-63

Abdykulova G.M, Klotsvog F.N., Khairullov D.S., Khusnutdinov R.A.. A new approach to the study of financial and cost proportions economy / / Problems of forecasting. - M: MAIK "Nauka", 1999 - № 4-p. - 19-26.

Khairullov D.S. Management of social and economic security of the region / / Economic Herald Tatarstan-№ 1 Kazan Tatarstanstat 2012 - № 1-p-44-47.

Tatarstanstat. Statistical Yearbook of Kazan, 2012.-521p

National Accounts of the Republic of Tatarstan. Statistical Compendium 2010 Kazan: Tatarstanstat 2011-86p. 